\title{
Heterologous gene expression and secretion in Bifidobacterium longum
}

\author{
MyeongSoo PARK ${ }^{\mathrm{a}}$, JeongMin $\mathrm{SEO}^{\mathrm{a}}$, JinYong $\mathrm{KIM}^{\mathrm{b}}$, GeunEog JI ${ }^{\mathrm{a}, \mathrm{b}^{*}}$ \\ a Research Center, BIFIDO Co., Ltd. 151-818, Seoul, Korea \\ b Dept. Food and Nutrition, Seoul National Univ. 151-057, Seoul, Korea
}

\begin{abstract}
Strains of the genus Bifidobacterium are used in fermented dairy products where they are supposed to exert health-promoting effects on the consumers. To study Bifidobacterium sp. properties, to improve the strains or to use them for safe delivery of vaccinal or anticarcinogenic polypeptides into the human digestive tract, it is strategically important to develop a system for heterologous expression and secretion. For this purpose, we constructed pBESAF2, a secretion vector based on the $\alpha$-amylase expression and secretion signals (ESS) isolated from Bifidobacterium adolescentis. The signal peptide was analyzed in silico and its cleavage site was experimentally determined by $\mathrm{N}$ terminal sequencing of the mature amylase. To validate this secretion vector, the phytase structural gene from Escherichia coli MC4100 was cloned downstream of the ESS and the resulting plasmid was introduced into Bifidobacterium longum MG1. Recombinant cells expressed phytase (with activity up to $21.1 \mathrm{U}$ ) and more than $95 \%$ of the phytase activity was found in the culture medium, suggesting that $E$. coli phytase can be produced and properly secreted and folded when expressed in B. longum. This is the first report of the development of a secretion vector for bifidobacteria and its use in a heterologous protein export in B. longum. This work is the first step towards the production of other proteins of food or therapeutic interest in bifidobacteria.
\end{abstract}

\section{Bifidobacterium / secretion / heterologous expression}

Résumé - Expression hétérologue et sécrétion chez Bifidobacterium longum. Certaines souches du genre Bifidobacterium sont utilisées dans des produits laitiers fermentés pour leurs potentiels effets bénéfiques sur la santé de l'hôte. Pour étudier les propriétés de Bifidobacterium sp., pour améliorer les souches ou pour les utiliser afin de délivrer des protéines vaccinales ou anticancéreuses dans le tube digestif de l'homme, il est stratégiquement primordial de développer un système d'expression et sécrétion hétérologue pour Bifidobacterium sp. À cette fin, nous avons construit pBESAF2, un vecteur de sécrétion utilisant des signaux d'expression et de sécrétion (SES) d'une amylase isolée de Bifidobacterium adolescentis. Le peptide signal a été analysé in silico et son site de clivage a été déterminé par séquençage amino-terminal de l'amylase mature. Pour valider ce vecteur de sécrétion, le gène spécifiant la phytase d'Escherichia coli MC1400 a été cloné en aval des SES et le plasmide résultant a été introduit dans B. longum MG1. Les bactéries recombinantes exprimaient la phytase (avec une activité allant jusqu'à 21,1 U) et plus de $95 \%$ de l'activité phytase était détectée dans le surnageant de culture. Ce travail décrit la mise au point du premier vecteur de sécrétion spécifiquement développé pour Bifidobacterium ainsi que son utilisation chez B. longum pour exprimer et sécréter une forme active de la phytase d'E. coli. Ce résultat ouvre la voie à la production d'autres protéines d'intérêt agro-alimentaire ou thérapeutique.

\section{Bifidobacterium / sécrétion / expression hétérologue}

\footnotetext{
* Corresponding author: geji@bifido.com
} 


\section{INTRODUCTION}

Bifidobacterium species are non-pathogenic, Gram-positive, anaerobic bacteria, which inhabit the intestinal tract of humans and animals [13]. In breast-fed infants, bifidobacteria represent more than $90 \%$ of the gut bacterial population [6]. Bifidobacteria have been proven to exert health-promoting effects on the host by maintaining intestinal microflora balances, reducing lactose intolerance and serum cholesterol levels, increasing vitamin synthesis, and boosting the immune system and intrinsic anticarcinogenic activity of the host [14]. Reflecting these beneficial properties, Bifidobacterium spp. are commonly used in commercial, fermented dairy products [20]. However, since these beneficial effects are strain-dependent, ongoing research aimed at improving strain characteristics of Bifidobacterium is warranted. In this regard, the development of a vector system for Bifidobacterium is strategically important, not only for strain improvement, but also because Bifidobacterium is a promising delivery system into the human intestinal tract for other useful gene products, such as antigens, in live vaccine development.

In a previous study, we cloned and characterized an expression and secretion signal (ESS) from Bifidobacterium [9]. In the present report we applied the ESS element for the development of an expression-secretion system for the genus Bifidobacterium.

Phytases catalyze the hydrolysis of phytate, thereby releasing inorganic phosphate [19]. These enzymes are of interest for biotechnological applications, in particular for improving dietary phytate-phosphorus utilization by simple-stomached animals such as swine and poultry [4]. Similar to humans, these species have little endogenous phytase activity, thus most of their ingested phytate is excreted. Supplemental phytase in pig diets is effective at improving the bioavailability of phytatephosphorus, thereby decreasing phosphorus pollution [4].

In Escherichia coli, the appA gene codes for a bifunctional enzyme that exhibits both acid phosphatase and phytase activities.
These activities have a $\mathrm{pH}$ optimum of 4.5 and are stable at $\mathrm{pH}$ values from 2 to 10 , while their temperature optimum is $60{ }^{\circ} \mathrm{C}$ [18]. The mature AppA protein $\left(45 \mathrm{~kg} \cdot \mathrm{mol}^{-1}\right)$ is localized in the periplasmic protein of E. coli, while the AppA precursor contains a N-terminal signal peptide of 22 amino acids [5]. Manner et al. [12] studied the effectiveness of an E. coli phytase, in comparison with a commercially available Aspergillus phytase, at improving the bioavailability of phosphorus in broilers, layers and young pigs. They observed that E. coli consistently enhanced the availability of phytate in the same range or slightly more effectively than Aspergillus phytase, although the magnitude of this effect was quite small in layers and pigs.

In this report, we constructed an expression and secretion system using the genus Bifidobacterium and used it to express and secrete the E. coli AppA phytase in B. longum MG1.

\section{MATERIALS AND METHODS}

\subsection{Bacterial strains, media and plasmids}

The bacterial strains and plasmids used in this study are listed in Table I. E. coli DH5 $\alpha$ was cultured at $37^{\circ} \mathrm{C}$ in Luria broth with vigorous shaking. Ampicillin was used at a concentration of $50 \mu \mathrm{g} \cdot \mathrm{mL}^{-1}$ and chloramphenicol at $3 \mu \mathrm{g} \cdot \mathrm{mL}^{-1}$ for the selection of transformed bacteria. Bifidobacterium strains were grown in Brain Heart Infusion (BHI) broth (Difco, Detroit, USA) and MRS medium (Difco, Detroit, USA) supplemented with $0.05 \%$ (w/v) L-cysteine $\mathrm{HCl}$ at $37^{\circ} \mathrm{C}$.

\subsection{General cloning techniques and sequence analysis}

Plasmid DNA preparation from E. coli, restriction enzyme digestion, ligation and transformation of $E$. coli were carried out according to the procedure described by Sambrook et al. [21]. Plasmid DNA from 
Table I. Bacterial strains and plasmids.

\begin{tabular}{|c|c|c|}
\hline Strain or plasmid & Relevant characteristics & Source or reference \\
\hline \multicolumn{3}{|l|}{ Bifidobacterium strains } \\
\hline B. adolescentis INT57 & Source of ESS & {$[8]$} \\
\hline B. longum MG1 & Transformation host & {$[16]$} \\
\hline \multicolumn{3}{|l|}{ E. coli strains } \\
\hline DH5 $\alpha$ & Cloning host & [7] \\
\hline MC4100 & Source of phytase gene (appA) & {$[3]$} \\
\hline \multicolumn{3}{|l|}{ Plasmids } \\
\hline $\mathrm{pBES} 2$ & $\begin{array}{l}\mathrm{Cm}^{\mathrm{r}}, \mathrm{Amp}^{\mathrm{r}} ; \text { E. coli-Bifidobacterium } \\
\text { shuttle vector }\end{array}$ & {$[16]$} \\
\hline pYBamy59 & $\begin{array}{l}\mathrm{Cm}^{\mathrm{r}}, \mathrm{Amp}^{\mathrm{r}} ; \mathrm{pBES} 2 \text { derivative containing } \\
\text { a functional promoter and the structural } \\
\text { gene for ESS }\end{array}$ & [9] \\
\hline pBESAF2 & $\begin{array}{l}\mathrm{Cm}^{\mathrm{r}}, \mathrm{Amp}^{\mathrm{r}} \text {; } \mathrm{pBES} 2 \text { derivative containing } \\
\text { a functional promoter and the ESS }\end{array}$ & This study \\
\hline pBESAF2-appA & $\begin{array}{l}\mathrm{Cm}^{\mathrm{r}}, \mathrm{Amp}^{\mathrm{r}} ; \mathrm{pBES} 2 \text { derivative containing } \\
\text { a functional promoter and ESS and } E \text {. coli } \\
\text { phytase gene }(\operatorname{app} A)\end{array}$ & This study \\
\hline
\end{tabular}

Bifidobacterium strains was prepared as described by Park et al. [15]. Nucleotide sequences were determined using the BigDye terminator and the ABI377 system (PE Applied Biosystems, Foster City, CA, USA). All restriction and modifying enzymes were purchased from Promega (Madison, WI, USA). Sequence analysis of the cloned gene was also performed using the BigDye terminator and the ABI377 system (PE Applied Biosystems, CA, USA). Signal sequence analysis was performed using the SignalP software program held at http:// www.cbs.dtu.dk/Services/SignalP/ [2].

\subsection{PCR amplification of DNA}

In a previous study, a 2477 bp DNA fragment containing $a m y B$, an amylase gene, was isolated from $B$. adolescentis INT57 and analyzed [9]. It was cloned into pBES2 to construct pYBamy59 and used to transform B. longum MG1, resulting in MG1 (amy59). The ESS was amplified from pYBamy59 using primers ESS-F and ESS-R (Tab. II). For amplification of the appA gene, genomic DNA was prepared from E. coli MC4100 using GeneReleaser ${ }^{\circledR}$
(Bioventure Inc., Murfreesboro, TN, USA) and primers appA-F and appA-R (Tab. II) were used. For the design of the primer set, the nucleotide sequence of the appA gene was obtained from GenBank under the accession number M58708. The PCR reaction was performed as follows: $25 \mathrm{ng}$ of DNA in a final volume of $50 \mu \mathrm{L}$ containing deoxyribonucleoside triphosphate $(0.25$ to $0.5 \mathrm{mmol} \cdot \mathrm{L}^{-1}$ each), oligonucleotides $\left(50 \mathrm{pmol} \cdot \mathrm{L}^{-1}\right)$ (Tab. II), and 1.0 to $3.0 \mathrm{U}$ of LA-Taq polymerase (TAKARA, BIO Inc., Shiga, Japan). Amplification was performed on a PROGENE (Techne, Cambridge, UK) with 30 cycles of denaturation at $95^{\circ} \mathrm{C}$ for $30 \mathrm{sec}$ ( $5 \mathrm{~min}$ in the first cycle), annealing at $60{ }^{\circ} \mathrm{C}$ for $60 \mathrm{~s}$, and elongation at $72{ }^{\circ} \mathrm{C}$ for $90 \mathrm{~s}$ (10 $\mathrm{min}$ in the last cycle).

\subsection{Transformation of Bifidobacterium}

Electrocompetent cells of $B$. longum MG1 were prepared according to the method of Argnani et al. [1] with minor modifications. B. longum MG1, grown in MRS-cysteine medium overnight, was inoculated into 
Table II. Oligonucleotides used for PCR amplification.

\begin{tabular}{|c|c|}
\hline Primer & Sequence* \\
\hline ESS-F & 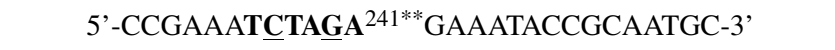 \\
\hline ESS-R & 5'-CTCGCCCATGGATCCC ${ }^{879}$ GCCAGTCCGTAATGCTTGCG-3' \\
\hline AppA-F & 5'-GTCTGGATCCATGC ${ }^{250}$ AGAGTGAGCCGGAGCTGAAG-3' \\
\hline AppA-R & 5'-GTCATCGAATT ${ }^{1524}$ CAGAGCATTCAGGTAACT-3' \\
\hline
\end{tabular}

* Underlined nucleotides represent modifications with regard to the original gene and the bold letters represent restriction enzyme recognition sites.

** Nucleotide number of original sequence of each gene.

fresh MRS-cysteine medium containing $0.2 \mathrm{~mol} \cdot \mathrm{L}^{-1}$ sucrose and cultivated anaerobically at $37{ }^{\circ} \mathrm{C}$. When the culture reached $\mathrm{OD}_{600}=0.45$, cells were harvested by centrifugation $(8000 \mathrm{~g})$ for $10 \mathrm{~min}$ and washed twice using $0.2 \mathrm{~mol} \cdot \mathrm{L}^{-1}$ sucrose solution. The pellet was resuspended in 1/320 of the initial volume of $0.2 \mathrm{~mol} \cdot \mathrm{L}^{-1}$ sucrose. One microgram of DNA was thoroughly mixed with $80 \mu \mathrm{L}$ of competent cells and transferred to a pre-chilled cuvette for application of an electric pulse using a Gene Pulser apparatus (Bio-Rad, Hercules, CA, USA), which was set at $12.5 \mathrm{kV} \mathrm{cm}^{-1}, 200 \Omega$ and $40 \mu \mathrm{F}$. The transformed cells were selected on MRS medium containing $3 \mu \mathrm{g} \cdot \mathrm{mL}^{-1}$ of chloramphenicol and $0.2 \mathrm{~mol} \cdot \mathrm{L}^{-1}$ sucrose.

\subsection{Analysis of intracellular and extracellular phytase activity}

Phytase activity was measured using sodium phytate as a substrate [17]. One phytase unit was defined as the activity that releases one $\mu$ mole of inorganic phosphorus from sodium phytate per minute at $37^{\circ} \mathrm{C}$. B. longum MG1 strain with pBES2 was used as a control because it showed no apparent phytase activity. The transformed cells were grown in a modified MRS medium (glucose 2\%, Tween $800.1 \%$, yeast extract $0.5 \%$, ammonium citrate $0.2 \%$, peptone $0.5 \%$, sodium acetate $0.5 \%, \mathrm{CaCl}_{2} 0.05 \%$, magnesium sulfate $0.01 \%$, maleic acid $0.01 \%$, sodium carbonate $0.2 \%$, L-cysteine $\cdot \mathrm{HCl}$ $0.05 \%$, and manganese sulfate $0.005 \%$ ). Aliquots of $1 \mathrm{~mL}$ of culture broth were taken at various time points. Cells were collected by centrifugation at $8000 \mathrm{~g}$ for $5 \mathrm{~min}$ in a microfuge and $50 \mu \mathrm{L}$-aliquots of the broths were prepared. In addition, the harvested cells were washed twice with $1 \mathrm{~mL}$ of $0.1 \mathrm{~mol} \cdot \mathrm{L}^{-1}$ sodium acetate buffer ( $\left.\mathrm{pH} 5.4\right)$ and disrupted by sonication. The cell debris was precipitated by centrifugation at $10000 \mathrm{~g}$ for $15 \mathrm{~min}$ at $4{ }^{\circ} \mathrm{C}$. To each sample, $350 \mu \mathrm{L}$ of $0.1 \mathrm{~mol} \cdot \mathrm{L}^{-1}$ sodium acetate buffer ( $\mathrm{pH} 5.4$ ) and $4 \mu \mathrm{L}$ of $0.1 \mathrm{~mol} \cdot \mathrm{L}^{-1}$ sodium phytate were added and incubated at $58{ }^{\circ} \mathrm{C}$ for $30 \mathrm{~min}$. Fifty $\mu \mathrm{L}$ of the reaction sample were transferred into a fresh tube and $50 \mu \mathrm{L}$ of $1 \mathrm{~mol} \cdot \mathrm{L}^{-1}$ citric acid and $400 \mu \mathrm{L}$ of AAM solution [100 $\mu \mathrm{L}$ of $10 \mathrm{mmol} \cdot \mathrm{L}^{-1}$ ammonium molybdate, $100 \mu \mathrm{L}$ of $5 \mathrm{~N} \mathrm{H}_{2} \mathrm{SO}_{4}$ and $200 \mu \mathrm{L}$ of acetone] were added and mixed. The absorbance was measured at $450 \mathrm{~nm}$.

\subsection{Protein purification and $\mathrm{N}$-terminal sequencing}

To purify $\alpha$-amylase from the supernatant of MG 1 containing pYBamy59, cells were grown anaerobically in $1000 \mathrm{~mL}$ starch-BHI liquid media containing $0.05 \%$ L-cysteine $\cdot \mathrm{HCl}(\mathrm{w} / \mathrm{v})$ and chloramphenicol $\left(3 \mu \mathrm{g} \cdot \mathrm{mL}^{-1}\right)$ at $37^{\circ} \mathrm{C}$. The supernatant was separated from the cell pellet by centrifugation at $8000 \mathrm{~g}$ for $10 \mathrm{~min}$ at $4{ }^{\circ} \mathrm{C}$. Proteins in the supernatant were precipitated with $75 \%$ ammonium sulfate and centrifuged at $3000 \mathrm{~g}$ for $30 \mathrm{~min}$ at $4{ }^{\circ} \mathrm{C}$. The pellet was dissolved in $100 \mathrm{mmol} \cdot \mathrm{L}^{-1}$ sodium acetate buffer ( $\mathrm{pH}$ 5.5). To remove ammonium sulfate from the concentrated protein solution, dialysis was carried out in $20 \mathrm{mmol} \cdot \mathrm{L}^{-1}$ sodium acetate buffer ( $\mathrm{pH}$ 5.5) using the 
M 9

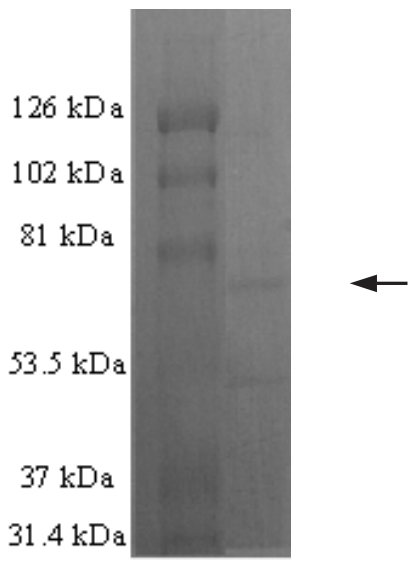

Figure 1. Purification of amylase from culture broth of MG1 (amy59). M, size marker; 9, fraction number of FPLC elutes; $\leftarrow$ amylase band confirmed by activity staining and used for $\mathrm{N}$-terminal sequence analysis.

Slide-A-Lyzer Dialysis Cassette (Pierce, Rockford, IL, USA) at $4{ }^{\circ} \mathrm{C}$. Subsequently, this protein solution was concentrated using microcon centrifugal filter devices (Millipore, Billerica, MA, USA) and then stored at $4{ }^{\circ} \mathrm{C}$. For ion exchange chromatography, a UPC-900, P-920 and Fac-920 (AKTAFPLC, Amersham Pharmacia Biotech, Sweden), and a Hi Trap_Q_HP_1mL column (Amersham Pharmacia, Uppsala, Sweden) were used. The proteins were consecutively eluted with $0 \mathrm{~mol} \cdot \mathrm{L}^{-1} \mathrm{KCl}$ (in $25 \mathrm{mmol} \cdot \mathrm{L}^{-1}$ potassium phosphate buffer) to $1 \mathrm{~mol} \cdot \mathrm{L}^{-1} \mathrm{KCl}$ (in $25 \mathrm{mmol} \cdot \mathrm{L}^{-1}$ potassium phosphate buffer). The purified protein was separated by SDS-polyacryamide gel electrophoresis. Activity staining was performed to chase the amylase protein band as described by Lee et al. [10]. To analyze the $\mathrm{N}$-terminal sequence of amylase from the MG1 (amy59), the target protein was transferred to a PVDF membrane according to the method of Sambrook et al. [21]. The eluted protein was sequenced using a Procise 491 HT protein sequencer (Applied Biosystems, USA).

\section{RESULTS AND DISCUSSION}

\subsection{Determination of the cleavage site}

For the precise determination of the cleavage site of the ESS gene, amylase was purified from MG1 (amy59), separated using SDS-PAGE and transferred as described in Materials and Methods (Fig. 1). The purified amylase had the $\mathrm{N}$-terminal amino acid sequence: $\mathrm{Ser}^{45}$ - $\mathrm{Thr}^{46}$ - $\mathrm{Asp}^{47}$ - $\mathrm{Arg}^{48}$ $\mathrm{Asp}^{49}-\mathrm{Ser}^{50}$. This coincides with the predicted cleavage site of this protein. In general, signal peptides are 14-25 amino acids long and consist of three identifiable domains, i.e., the amino (N-), hydrophobic $(-\mathrm{H}-)$, and carboxy-terminal (-C) regions (Fig. 2). The N-region is rich in positivelycharged amino acids, and is followed by a hydrophobic region that tends to organize itself into a $\alpha$-helical conformation when brought into contact with the membrane lipid phase. The C-terminal region is hydrophilic and contains the signal peptide cleavage site that is recognized by the relevant signal peptidase. Hydropathy plot analysis (TMHMM program held at http://www.cbs.dtu.dk/ services/) revealed 23 amino acid residues (from 21 to 43; VVV-----AAQ) of the putative trans-membrane sequence with a high score. This site corresponds to a general Ala$\mathrm{X}$-Ala cleavage site. In addition, the $\mathrm{N}$-region frequently contains the positively-charged amino acid residues lysine and arginine [22]. Very similar features of secretion signals from Bifidobacterium have been revealed by a comparative genomics approach [11].

The ESS of amylase from INT-57 corresponded well with the general characteristics of reported signal peptides. Thus, the signal peptide identified in the present study may be used for secreting recombinant proteins in bifidobacteria.

\subsection{Construction of a secretion vector and cloning of the phytase gene}

Initially, the ESS containing the promoter and signal peptide regions of the $a m y B$ gene was amplified as described above. The partial sequence of the ESS gene is shown in Figure 3 . The amplified product (664 bp) was digested using $\mathrm{Xba \textrm {I }}$ and $\mathrm{BamHI}$ and ligated 


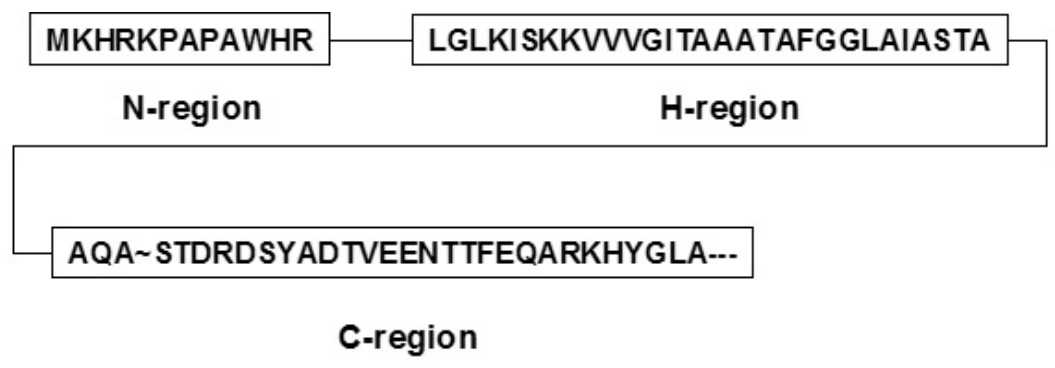

Figure 2. Three domains of the ESS gene. N-region, positively-charged domain; H-region, hydrophobic domain; C-region, hydrophilic domain with cleavage site.

\begin{abstract}
236 TCTAGAGAAATACCGCAATGCACGGCAAATTCAATTAAACGCAACTCTTCATAGGCCACTTAAAC
301 AAACCACCAC CCCATCAAAT TGGATAGAGC ATATACAAGC CCACATCCAG CAGCACCCCC

361 GTACCCCTAC TTGCGCAAAT GAGAAAGATT TGCAGGGTTG ACGCATCGAC AACAACTGGA

421 TTGCATTTTC AGGGCATCGC CGAATATACT CCCACCACAC AACAAGTTAG GGTGGTACAA

481 AACACCATCA ATTAAgTACC ACCTTTGCAA ACATTTTCAC AAATGAAAgA GTTGTTtCAg

541 CAACGATTTT CATTGTTTTT TCCAAGGCTT TTCGCACTTT AGCACCCTAG AAAAGGTATA

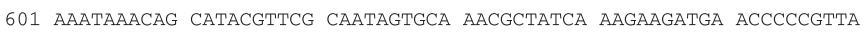

661 AAgGGATtGA AgAAAAgGA TAAAgGAGCC ATG AAA CAT CGG AAA CCC GCA CCG GCC TGG

$\begin{array}{lllllllllllllllllll}\text { RBS } & \text { M } & \text { K } & \text { H } & \text { R } & \text { K } & \text { P } & \text { A } & \text { P } & \text { A } & \text { W }\end{array}$

721 CAT AGg CTG GGg CTG AAg ATT AGC AAg AAA GTg GTG GTC GGC ATC ACC GCC GCG GCG ACC $\begin{array}{lllllllllllllllllllllllll}\mathrm{H} & \mathrm{R} & \mathrm{L} & \mathrm{G} & \mathrm{L} & \mathrm{K} & \mathrm{I} & \mathrm{S} & \mathrm{K} & \mathrm{K} & \mathrm{V} & \mathrm{V} & \mathrm{V} & \mathrm{G} & \mathrm{I} & \mathrm{T} & \mathrm{A} & \mathrm{A} & \mathrm{A} & \mathrm{T} & & 30\end{array}$

781 GCC TTC GGC GGA CTG GCA ATC GCC AGC ACC GCA GCA CAG GCC AGC ACC GAT CGC GAC AGC

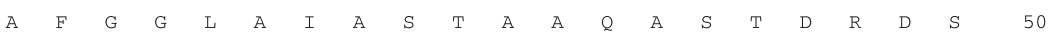

841 TAC GCC GAC ACC GTT GAA AAC ACC ACG TTC GAA CAG GCG CGC AAG CAT TAC GGA CTG GCG

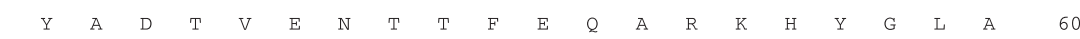

901 GGA TCC ATG CAG AGT GAG CCG GAG CTG AAG

$\begin{array}{llllllllllllll}\text { G } & S & M & Q^{23} & S & E & P & E & L & K & 70\end{array}$

Figure 3. The partial sequence of the ESS gene containing the promoter region and signal sequence of the $a m y B$ gene. The putative promoter regions 1 (563-612 bp) and $2(471-520 \mathrm{bp})$ and the ribosome binding site (RBS $684 \mathrm{bp}$ ) were detected by promoter prediction program (data not shown). The full sequence of the $a m y B$ gene is available from GenBank under the accession number AY240946. The nucleotide sequence from $907 \mathrm{bp}$ and the amino acid sequence are the cloned phytase gene.

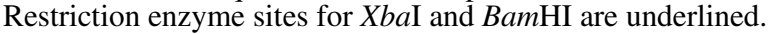


into $\mathrm{pBES} 2$ digested with the same enzymes to construct pBESAF2. Subsequently, the gene structure and termination sequences of appA (from $250 \mathrm{bp}$ to $1534 \mathrm{bp}$ of appA; GenBank accession number M58708) were also PCR-amplified (1297 bp) and digested with BamHI and EcoRI. These were ligated inframe with the ESS gene and the construct was termed pBESAF2-appA (Fig. 4). Cloning was performed in E. coli DH5 $\alpha$ and the integrity of the plasmid construct was confirmed by restriction pattern analysis. pBESAF2-appA prepared from E. coli DH5 $\alpha$ was used to transform $B$. longum MG1 by electrotransformation, resulting in MG1(appA). PCR amplification using AppA-F and AppA-R for the plasmid prepared from MG1 (appA) produced an amplified DNA band of approximately $1.3 \mathrm{~kb}$, which corresponds to the size of appA.

\subsection{Phytase activity of MG1 (appA)}

Phytase activity of MG1 (appA) was measured as described in Materials and Methods at each time point and the results are shown in Figure 5 . More than $95 \%$ of phytase activity in MG1 (appA) was detected in the culture supernatant. This pattern of phytase activity was the same as that of amylase of B. adolescentis INT57 (data not shown). It shows that

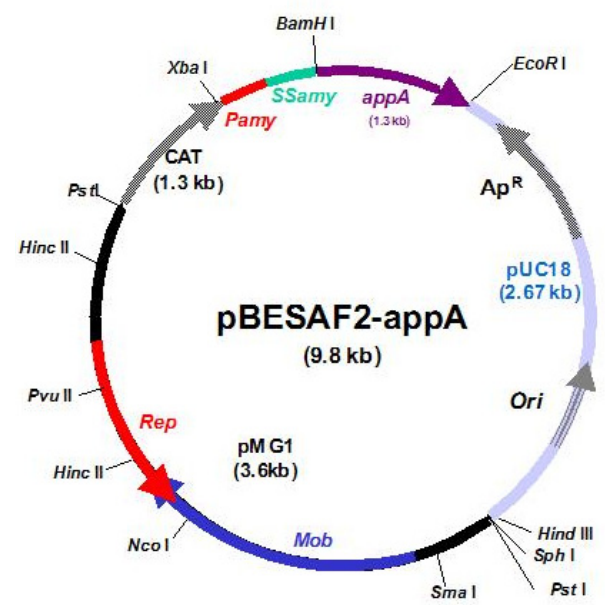

Figure 4. Genetic map of the expression vector pBESAF2-appA. Pamy, promoter of $a m y B$; SSamy, $72 \mathrm{~N}$-terminal amino acids of $a m y B$, the first 44 amino acids represent the secretion signal peptide sequence and the remainder encompass the mature $\mathrm{N}$-terminus of amylase; appA, phytase gene from E. coli MC4100; ApR and CAT, ampicillin and chloramphenicol resistance genes, respectively; Ori, origin of replication of E. coli; Rep and Mob, replication initiation and plasmid mobilization determinant of Bifidobacterium, respectively; pMG1, plasmid originated from B. longum MG1.

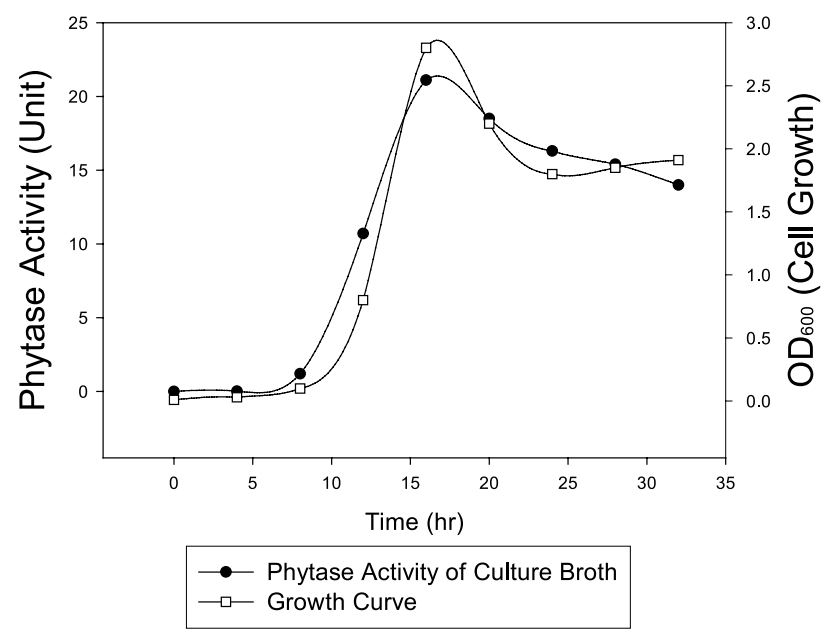

Figure 5. The growth curve and phytase activity of MG1 (appA) at indicated time points. - $\bullet-$, phytase activity of culture broth; - $\square$-, growth curve of MG1 (appA). 
the activity follows the growth pattern and that therefore the expression of the fusion gene appears to be constitutive.

In this report, we characterized ESS of the $a m y B$ gene from $B$. adolescentis INT57 and constructed a secretion vector, $\mathrm{pBESAF} 2$, using this information. The intracellular phytase gene from E.coli was successfully expressed and secreted by B. longum into the culture broth by using this system. These results show that $B$. longum is able to produce, secrete, and fold into an active conformation a heterologous enzyme. We expect that pBESAF2 will be a good vehicle for molecular modification and improvement of the genus Bifidobacterium.

Acknowledgements: This work was supported by the 21C Frontier Microbial Genomics and Applications Center Program, Ministry of Science and Technology (MG02-0303-001-1-0-0), Republic of Korea.

\section{REFERENCES}

[1] Argnani A., Leer R.J., van Luijk N., Pouwels P.H., A convenient and reproducible method to genetically transform bacteria of the genus Bifidobacterium, Microbiology 142 (1996) 109-114.

[2] Bendtsen J.D., Nielsen H., von Heijne G., Brunak S., Improved prediction of signal peptides: SignalP 3.0, J. Mol. Biol. 340 (2004) 783-795.

[3] Casadaban M.J., Transposition and fusion of the lac genes to selected promoters in Escherichia coli bacteriophage lambda and mu, J. Mol. Biol. 104 (1976) 541-555.

[4] Choi W.C., Oh B.C., Kim H.K., Kang S.C., Oh T.K., Characterization and cloning of phytase from Escherichia coli WC7, Kor. J. Microbiol. Biotechnol. 30 (2002) 1-7.

[5] Dassa J., Marck C., Boquet P.L., The complete nucleotide sequence of the Escherichia coli gene appA reveals significant homology between $\mathrm{pH} 2.5$ acid phosphatase and glucose-1-phosphatase, J. Bacteriol. 172 (1990) 5497-5500.

[6] Guarner F., Malagelada J.R., Gut flora in health and disease, Lancet 361 (2003) 512-519.

[7] Hanahan D., Studies on transformation of Escherichia coli with plasmids, J. Mol. Biol. 166 (1983) 557-580.

[8] Ji G.E., Han H.K., Yun S.W., Rhim S.R., Isolation of amylolytic Bifidobacterium sp. Int57 and characterization of amylase, J. Microbiol. Biotechnol. 2 (1992) 85-91.
[9] Kang Y.H., Development of foreign gene expression system for Bifidobacterium longum GE1, Thesis for the Degree of Master, Seoul Natl. Univ., 2001.

[10] Lee S.K., Kim Y.B., Ji G.E., Purification of amylase secreted from Bifidobacterium adolescentis, J. Appl. Microbiol. 83 (1997) 267-272.

[11] MacConaill L.E., Fitzgerald G.F., van Sinderen D., Investigation of protein export in Bifidobacterium breve UCC2003, Appl. Environ. Microbiol. 69 (2003) 6994-7001.

[12] Manner K., The effectiveness of an Escherichia coli phytase in improving phosphorous and calcium bioavailabilities in poultry and young pigs, Arch. Tierernaehr. 54 (2001) 117-126.

[13] Mitsuoka T., Intestinal flora and ageing, Nutr. Rev. 50 (1992) 438-446.

[14] Oatley J.T., Rarick M.D., Ji G.E., Linz J.E., Binding of aflatoxin B1 to bifidobacteria in vitro, J. Food Prot. 63 (2000) 1133-1136.

[15] Park M.S., Lee K.H., Ji G.E., Isolation and characterization of two plasmids from Bifidobacterium longum, Lett. Appl. Microbiol. 25 (1997) 5-7.

[16] Park M.S., Moon H.W., Ji G.E., Molecular characterization of plasmid from Bifidobacterium longum, J. Microbiol. Biotechnol. 12 (2003) 457-462.

[17] Piddington C.S., Houston C.S., Paloheimo M., Canrell M., Miettinen-Oinonen A., Nevalainen H., Rambosek J., The cloning and sequencing of the genes encoding phytase (phy) and pH 2.5-optimum acid phosphatase (aph) from Aspergillus niger ver. awamori, Gene 133 (1993) 55-62.

[18] Rodriguez E., Han Y., Lei X.G., Cloning sequencing and expression of an Escherichia coli acid phosphatase/phytase gene(appA2) isolated from pig colon, Biochem. Biophys. Res. Commun. 257 (1999) 117-123.

[19] Rodriguez E., Porres J.M., Han Y.M., Lei X.L., Different sensitivity of recombinant Aspergillus niger phytase (r-PhyA) and Escherichia coli $\mathrm{pH} 2.5$ acid phosphatase (rAppA) to trypsin and pepsin in vitro, Arch. Biochem. Biophy. 365 (1999) 262-267.

[20] Salminen M.K., Jarvinen A., Saxelin N., Tynkkynen S. Rautelin H., Valtonen V., Increasing consumption of Lactobacillus $\mathrm{GG}$ as a probiotic and the incidence of lactobacilli bacteraemia in Finland, Clin. Microbiol. Infect. 7 (2001) 1-394.

[21] Sambrook J., Fritsch E.F., Maniatis T., Molecular cloning: A Laboratory Manual, 2nd edn., Cold Spring Harbor Laboratory Press, Cold Spring Harbor, NY, USA, 1989.

[22] von Heijne G., Abrahmsen L., Species-specific variation in signal peptide design. Implication for protein secretion in foreign hosts, FEBS Lett. 244 (1998) 439-446. 